\title{
The Expansion of State Authority Over the Xeighbouring States Through Informal Migration Controls: The Case of Ilungary's Control over Serbia
}

\author{
Tasawar ASIIR MF, Lmul KORKUT \& Daniel GIOLL IF
}

\begin{abstract}
1bstract: Our preliminary fieldwork shows that there is large scale agreement between the migration and border authorities of I Iungary and Serbia on the names of ass lum seekers before they are allowed into to the Ilungarian transit zones and apply for international protection in Hungary. The list, proposed by the Serbian Commissariat for Refugees (SCR) and approved by the Ilungarian border authorities, is communicated through the use of community leaders from the Serbian reception centre. Itungary's motive behind heeping its cooperation with Serbia informal is to conceal the existence of cooperation between both states and to avoid legal challenges in the Court of Justice of the EU (C.JEU) and the European Court of Iluman Rights (ECIIIR). Therefore, the paper argues that the informalisation of migration management constitutes a significant challenge for the authoritv of the Geneva Convention Relating to the Status of Refugees t9.5 (hereinafter referred as the Refugee Convention). The paper further argues that I lungary's informal cooperation with Serbia is a form of expansion of the Ilungarian state authority under the principle of extraterritorial jurisdiction of a state. Therefore, despite informal nature of Itungary's migration cooperation with Serbia, the responsibility for violations of ass lum seekers rights in Serbia and their exclusion from international protection continues to engage I Hungary for the reason of having effective control on the migration management in Serbia.
\end{abstract}

Keywords: Asylum Seekers, Evclusion, Informalisation of Vigration, International protection, State responsibility, wrongful Act.

\section{(A) IXTRODUCCTIO)}

The principle of non-refoulement enshrined in Article 33 of the Refugee Convention has not been expressly recognised in the European Union (EU) treaty law. In the EU law, the principle of nonrefoulement has been recognised through the judgement of the ECIIIR in the case of /Iirsi.Jamaa and Others v. Ilaly.' The ECIIIR construed Article 3 of the ECIIR to include a prohibition on returning asylum seekers to territories where their lives and freedom could be threatened on account of race, religion, nationality, or membership of a particular social group. The Court held that ttaly could not evade its responsibility arising from Article 3 of the ECIIR by relying on the obligations arising from the bilateral agreement with Libya even if there was an express provision for the return of irregular migrants. In the EU Law, prohibition on returning asylum seekers to inhuman and degrading treatment is recognised

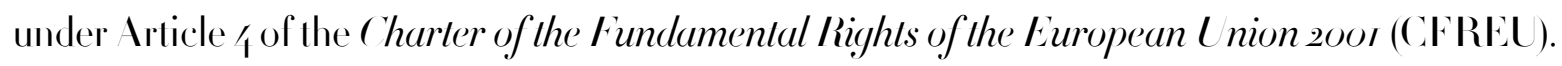

ar Irlicle published on.31 December 2019

Tasawar Ashraf is PhD) Student at Glasgow Caledonian Lniversity (U K). Email: Tasawar.ashraf a geu.ac.uk. Lmut Korkut is Professor of International Politics at Glasgow Caledonian U niversity (U K). Email: U mut.Korkut a geu.ac.uk. Daniel Grollai is PhI) Student at Glasgow Caledonian Universits (U K). Email: Daniel.Gvollai a gcu.ac.uk. This article was written within the contevt of the research project The European U nion's policies on asvlumi: confluences between the internal and the external dimensions' (DER-2017-82 $966-\mathrm{R}$ ), funded by the Spanish Vinistry of Economy and Competitiveness and FEDER, as well as the Jean Vonnet Chair EU Economic and Legal Integration for People, E LC A ${ }_{3} 2016$ (2017-2020).

' ECIIIR, IIirsi Jamaa and Others v Ilaly, Application no. 27765 og, European Court of Iluman Rights, 23 February 2012. 
To break free from the obligations arising from the EU and international human rights law, the EU Frontier Member States facing exceptional irregular arrivals leaned towards extraterritorial migration and asstum controls. To this end, the frontier Member States used development assistance, trade incentives and other returns to export their agendas of the securitisation of migration to third countries. ${ }^{2}$ Thereof, the expansion of state authority through bilateral externalisation agreements became the most preferred security approach of the EU frontier Member States. These externalisation agreements are widely available, but their practices are more challenging to determine. There are yet also informal practices that are built around such existing agreements - or sometimes in the absence of agreements.3 These informal migration controls not only undermine human security but also weaken the significance of the Refugee Convention and the EU Law. This makes us a question how come an EU Member State, which has made a solemn declaration to respect the Union laws and the human rights derived therein, can cause grave human rights violation extraterritorially?

Our paper looks at migration management in Hungary and Serbia to reflect on how Ilungary expands its state authority beyond its territorial limits to exercise control over the management of asylum in Serbia. During our field visits to Szeged and other small towns at Hungary Serbia border, as well as the Vojvodina province of Vorthern Serbia, we came across extensive involvement of Ilungary in the management of irregular migration in Serbia. Ilungary exercises informal control over the management of refugee camps in Serbia and informally imposes a profile of people to gain access to the Itungarian transit zones from Serbia and therefore seek asylum in Iungary. Given the informal nature of Ilungary's cooperation with Serbia, the paper examines wo interrelated questions; i.e. how does a state informally expand its authority over the neighbouring state to restrict irregular migration, and what is the future of international refugee protection given the informalisation of the securitisation of migration. The paper is divided into two parts. Part one analyses Hungarian practices of exercising state authority over neighbouring Serbia and to what extent Itungary can succeed in avoiding accountability for human rights violation using informal security mechanism. Part two examines the future of multilateral treaties of refugee protection considering the expansion of state authority through bilateral treaties.

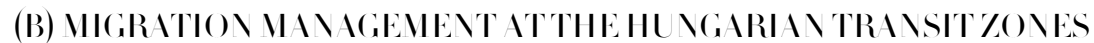

Existing scholarship shows Ilungary's ever-increasing emphasis on the securitisation of migration to control irregular arrivals in the country. ' Ilungary's increased emphasis on the securitisation of migration

\footnotetext{
2 A. Knoll and P. Veron, 'Migration and the nex Long-Term Budget: Key Choices for External Aclion', Ecdpm discussion

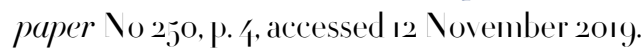

3 For example, Memorandum of Understanding on Cooperation in the Fields of Development, the Fight against Illegal Immigration, Human Trafficking and Fuel Smuggling and on Reinforeing the Security of Borders between the State of Libra and the Italian Republic (entered into force 2 February 2017).

C. Cantat, 'Governing Migrants and Refugees in Hungarv: Polities of Spectacle, Vegligence and Solidarity in a Securitising State' in S. Ilinger and R. Schweitzer (eds), Politics of (I)is)Inlegration, Springer International Publishing (2org) 183-199; D. Gyollai and A. Amatrudo, CControlling Irregular Migration: International Muman Rights Standards and the Ilungarian Legal Framework', I6(4) European .Journal of Criminology (2019) 432-155 |doi:10.1177/1/77370818772776); B. \agv, 'Ilungarian Ass lum Law and Policy in 201j 2016: Securitization Instead of Loval Cooperation', i7(6) German Law .Journal,
} 
is linked to the unprecedented arrival of asylum seekers, along with the latest wave of irregular arrivals in the EU.5 2015 was the year of the refugee crisis for the EU as nearly 1.2 million asylum seekers arrived in the EU. Out of these 1.2 million first time asylum applicants, nearly 17 1, foo asylum seekers applied for asylum in Ilungary alone, second highest after Germany which received 4,1,80o asylum seekers. ${ }^{7}$ Following these arrivals, the Ilungarian populist government of Viktor Orbán started a massive antimigration campaign and held the EU responsible for endangering security and identity of the Ilungarian as well as European people. ${ }^{8}$ The Orbán’s government constructed irregular migration as a foreign invasion on its border and consequently took series of security measures to restrict irregular arrivals from entering in the country, in disregard of the obligations arising from the EU Law.9

Since 2015, the Ilungarian government has repeatedly amended law LXXY on Asylum 2007 to provide effective mechanisms to restrict irregular arrivals in the country. The Government Decree promulgated in $205_{5}$ has expanded the list of safe third country of origin (STCO) and safe third country (STC) to exclude asylum seekers originating or transiting from the US States that do not have death plenty, the Member States of the EU, the Member States of the European Economic Area, the EU candidate states, Switzerland, Bosnia-I Ierzegovina, Kosovo, Canada, Australia, and Vew Zealand." Among the EU candidate states, initially, Turkey was not on the list of STCs, but later it was also included in the list."

Additionally, by the end of 2015 , Hungary built a barbed-wire fence on the Serbian and Croatian borders to stop cross border infiltration. ${ }^{2}$ Nong with the border fences, Hungary has established two transit zones which are on the Ilungarian soil but open towards Serbia. Theses Transit zones consist of a series of containers covered by wire fence all round and guarded by the Ilungarian armed forces. Every day, limited numbers of asylum seekers are admitted in the transit zone to process their asylum applications. Practically asylum seekers admitted in the transit zones remain detained in the transit zones for an indefinite period. Those admitted in the transit zones have the only option of leaving towards Serbia with consequences of their asylum application being terminated. Following the establishment of the transit zone, during the first three quarters of 2016, I lungary admitted only 20-3o asylum seekers on a daily quota basis, to register their asylum claims. The daily quota dropped from 20-30 to; to by the end of 2016,5

(2016) 1033-1081, accessed 13 Vorember 2019; J.W. Scotl, 'Ilungarian Border Politics as an Anti-Politics of the European L nion', Geopolitics (2018) 1-20| doi:10.1080 1/46500/5.2018.1548/388|; C. Thorleifsson, "Disposable Strangers: Far-Right Securitisation of Forced Migration in Ilungary', 25(3) Social Anthropology, (2017) 318-334|doi:10.1111/1/69-8676.12/20|.

Thorleifsson, supra n. 4, at 318.

6 V. Ceccorulli, 'Back to Schengen: The Collective Securitisation of the EU Free-Border Area', 12(2) II est European Politics (2019) 302-332, at 302 |doi:10.1080 01/02382.2018.1510196|; E. Quinn, The Refugee and Vigrant Crisis: Europe's Challenge, $105(419)$ Studies: An Irish Quarlerty Review (2016) $275^{-28} 8_{5}$, al 277.

7 Quinn, supra n. 6, at 277 and 278 .

8 Cantal, supre $\mathrm{n}$. 4 , al 186 and 187.

9 Ibid.

10 Ilungary: Government Decree 19I 2015 (I II.2I) on national designalion of safe countries of origin and safe third countries, (adopted 2 July 2015, entered into force I April 2016), § I and 2.

" European Council on Refugees and Eviles (ECRE), 'Country Report: Ilungarr?, (2018) 1-133, at 17 and 18 (accessed 7 November 2019).

${ }_{12}$ Ibid., al 17. 
in 2017, and a in 2018. ${ }^{3}$ The daily quola system has forced hundreds of asylum seekers, including Syrians, to wait on the Serbian side in the open air without any food provisions. Consequently, asylum seekers started to move towards Croatia to seek asylum there.

Despite the alarming report of the United Vations Working Group on Arbitrary Detention categorising Hungary's policy of holding asylum seekers in the transit zones, a deprivation of liberty under international law;'`́ the judgement of the Grand Chamber shows that the Court has granted Ilungary a wide margin of appreciation of its right to control borders. Itowever, despite this little relive, the infringement proceedings initiated by the EC, the judgement of the ECIIIRholding Itungary responsible for violation of Art 3 of the ECIIR, and flagrant criticism of international organisations has forced Itungary to look for other ways. Considering the stance of the ECIIIR in the cases of IItrsiand.Jammav Ilaly and Ilias and Ahmed $v$ Ilungary, Hungary intended to adopt such security practices, the responsibility for which could not be attributed to Hungary. Therefore, Ilungary externalised its securitisation policy through bilateral cooperation with neighbouring Serbia to informally control irregular arrivals extraterritorially.

Accordingly, Hungary adopted a policy of selective admission in the transit zones, to avoid the contradiction of the EU and international law. To pursue the policy of selective admission in the transit zones, Ilungary needed the cooperation of Serbia. I owever, any formal bilateral cooperation with Serbia was likely to bring more human rights challenges against Itungary for the reason of having effective control migration management in Serbia. ${ }^{5}$ Therefore, I Iungary opted to exercise informal control over irregular arrivals at the Ilungarian transit zones through informal cooperation with Serbia. Accordingly, Ilungary's securitisation policy transformed to a whole new level of informalisation.

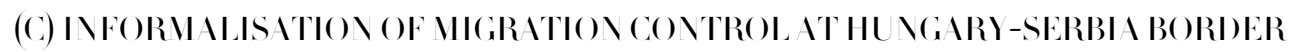

Since autumn 2016, the SCR has stopped asylum seekers from approaching the Ilungarian transit zones to claim protection. The SCR started to accommodate asylum seekers in temporary reception centres under the management of the Commissariat. ${ }^{16}$ Asylum seekers entering the temporary reception centres are asked whether they want to enter the Serbian or the Itungarian asylum system. Those wishing to enter Hungary are placed on the waiting list prepared by the SCR. ${ }^{17}$ The list is handed over to community leaders, chosen by the Serbian commissariat from the reception centre. The community leaders communicate the list to Ilungarian authorities at the transit centres. ${ }^{8}$ Since the start of the above process, only community leaders are allowed to stay in the pre-transit zones. At the Röszke transit zone, community leaders are

3 Ibid.

14 European Council on Refugees and Exiles, supra n. II, at 23.

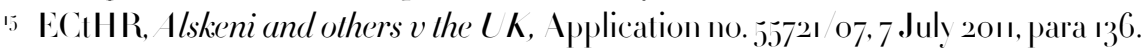

16 D. Gyollai, 'Hungary - Country Report: Legal and Policy Framework of Migration Governance', (2018) 1-77, at 31 accessed io November 2org).

17 European Council on Refugees and Exiles, 'Country Report: ILungary', supra n. II, at ı.

18 Ibid. 
accommodated in a heated tent, while at the Tompa transit zone, community leaders reside in an abandoned duty-free shop. ${ }^{19}$ The IIungarian authorities provide food to the community leaders.

There are no permanent community leaders because of a short stay of asy lum seekers in the reception centres. The SCR chooses community leader randomly from the asylum seekers entering in the reception centres. ${ }^{20}$ Once the Ilungarian authorities receive the list from the community leader, they review the list and decide on the names of people to be admitted in the transit zones. The revised list is handed back to the community leader, who then communicates the list to the SCR. Once the Serbian Commissariat receives the approved list from the Itungarian authorities, the Commissariat in forms the people accepted for admission in the transit zones. ${ }^{21}$ Those approved for admission in Itungarian transit zones are brought to the pre-transit zone a day before their admission. During the entire process, there is no direct communication between the Hungarian and Serbian authorities. ${ }^{22}$

Since March 2018, Ilungary has stopped admilting asylum seekers from the Serbian reception centres, except the Subotica reception centre. The Subotica reception centre has the capacity of accommodating a maximum of 60 people at a time. ${ }^{23}$ According to the SCR, the criteria for acceptance in the Subotica reception centre are the time of arrival and the extent of vulnerability. Therefore, the numbers of asylum seekers wishing to enter in the Subotica reception centres has increased while the centre's capacity to accommodate asylum seekers remains limited. Therefore, significant malpractices have been taking place to admit asylum seekers in the reception centre. During our visit to the centre, we noticed significant similarities between the profiles of the asylum seekers in the centre and the Hungarian recognition profile. We noticed that Afghan families formed the majority of asylum seekers accepted in the centre. It was also surprising that despite the amendment in the Asylum Act, which provided ground for the Itungarian authorities to declare an asylum application inadmissible for the reason of staving or travelling through Serbia, ${ }^{21}$ asylum seekers were still eager to enter the Subotica reception centre for admission in the Ilungarian transit zones.

According to the staff members of the SCR at the Subotica reception centre, most of the asylum seekers staying at the centre see Hungary as a transit state for the onward journey towards Western European states. Therefore, they negotiate with the Hungarian police for their admission in the Hungarian transit zones. ${ }^{25}$ The profiles of the asylum seckers aceepted in Subotica reception centre, and the practice of asylum seekers' negotiation with the Ilungarian police raised our concern about the presence of malpractices at the Hungarian-Serbian transit route. When we inquired different asylum seekers at the reception centre and staff member of the SCR, we came to know that some asylum seekers

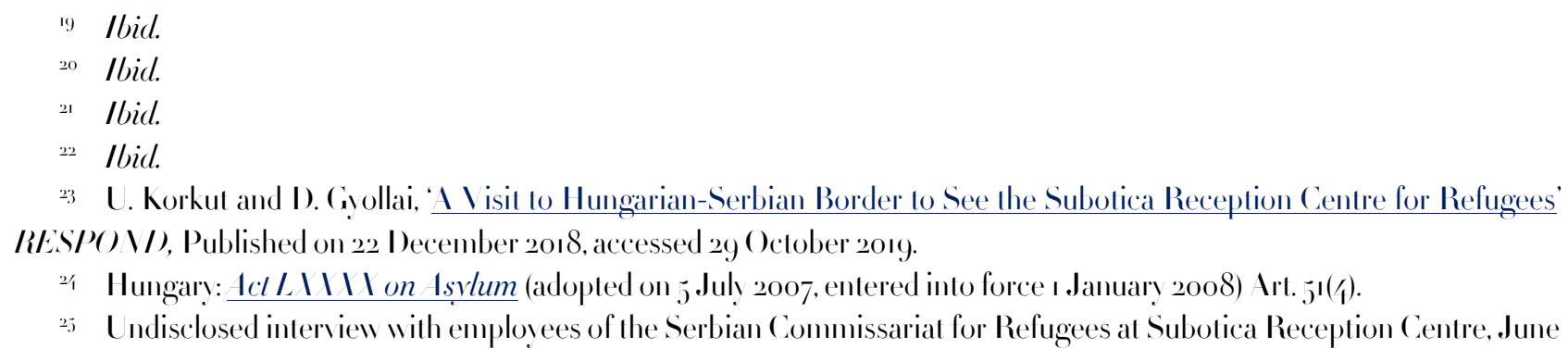


paid tooo euros to move their names on the top of the list for admission in the Itungarian transit zones. Further, the Ilungarian police officials were more likely to negotiate with asylum seekers who want to transit through Ilungary and willing to pay. We also heard the story of a single father accompanying a child, who paid 3000 Euros for admission in I Iungary and within a week he managed to reach Germany. ${ }^{26}$ Ilence, Ilungary's informal border security practices, in addition to extraordinary human rights abuses, are also corrupting the asy lum system of the EU and Serbia. This situation has created a new smuggling network in the backyard of the EU.

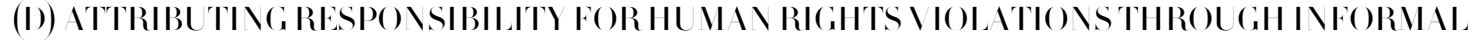
CONTROL

Asslum seekers' access to international protection based on the list violates Article 6(/) of the Asylum Procedures Directive (XPI)). ${ }^{27}$ The Article reads as the Member States shall ensure that a person, who has made an application for international protection, has an effective opportunity to lodge it as soon as possible. ${ }^{28}$ The practice of accepting asylum application only at the border transit zones, through the list profiling asylum seekers in the Serbian Subotica reception centre is against the Common Standards of the API). Article 13 (1) of the APD) allows the Member States to establish transit zones at the external borders. ${ }^{29}$ However, Ilungary only allows asy lum applications to be submitted within such transit zones where access is granted to a limited number of people after a prolonged delay..$^{3^{\circ}}$ Additionally, access to international protection based on the list violates Article 2 of the CFREU and Article I/4 of the ECIIR. ${ }^{3}$ The Articles prohibit discrimination based on any ground such as sex, race, colour, elhnic or social origin, religion, or nationality.

Furthermore, limited access to international protection at the Ilungarian transit zones also undermines the right to apply for asylum guaranteed under Article 18 of the CFREU. ${ }^{32}$ The United Vations Iligh Commissioner for Refugees (UNICR) has reported massive push backs from Serbia. ${ }^{33}$ According to U NIICR, asylum seekers entering Serbia are briefly deprived of their liberty, searched, and threatened, often with the use of force, to go back to North Macedonia. ${ }^{31}$ Therefore, asylum seekers exclusion from Ilungary is highly likely to cause indirect refoulement of asylum seekers, prohibited under

26 Ibid.

${ }_{27}$ Council of the European Union, Directive 2013.32 EU of the European Parliament and of the Council of 26 .June 2013 on common procedures for granling and wilhholding inlernalional prolection, (O.J L. I80 60, 29.6.2013, p. 60-9.5).

28 Ibid., Art. 6(1).

29 Ibid., Art. $13(\mathrm{I})$.

30 European Commission, Migralion and 1svlum: Commission Takes Furlher Sleps in Infringement Procedures against Ilungarv (accessed 27 Oclober 2org).

$3^{1}$ Council of the European I nion, Charler of the Fundamental Rights of the European I nion, 26 October 2012, 2012 C $3_{2}^{26}$ 02, Art. 21; Council of Europe, European Convention for the Prolection of IIuman Righls and Fundamenlal Freedoms, as

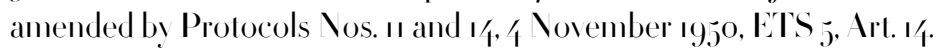

32 Council of the European Union, Charler of the Fundamenlal Rights of the European I nion, supra n. 3 I, Art. 18.

33 European Council on Refugees and Exiles (ECRE), 'Country Report: Serbia', i-82, at i6 (accessed 29 Oclober 2019 ).

3 Ibid. 
Article 33 of the Refugee Convention, ${ }^{35}$ Article 4 of the CFREU, ${ }^{36}$ and Article 3 of ECIIR ${ }^{37}$. Iowever, it remains unclear as to what extent Ilungary could be held responsible for informal exclusionary practices.

By restricting irregular arrivals at the Inungarian transit zones through informal security cooperation with Serbia, Ilungary has tried to establish that it no longer detains asylum seekers in the transit zones. Additionally, by approving the list, I Iungary authorises access to transit zones to only those asylum seekers, who are highly likely to be recognised as refugees. Therefore, Ilungary no longer expels asylum seekers from its transit zones as well. Accordingly, with the assistance of the SCR, Iungary has ensured that there are no more human rights challenges for arbitrary detention, inhuman and degrading treatment, and refoulement of asylum seekers. Therefore, this secret cooperation has helped I lungary to dissolve grounds of infringement proceeding triggered by the EC against Itungary. $3^{8}$ To attribute responsibility to Itungary for extraterritorial violation of human rights, we must establish Ilungary's effective control of on the migration management in Serbia, particularly at the Subotica reception centre. Therefore, we have to see to what extent a state can be held responsible for the acts of another state. Vevertheless, before attributing responsibility to Itungary of the acts of the SCR, we have to establish the existence of effective control of Hungary on the migration management in Serbia. In the present case, since communication between both states is done through the community leaders; therefore, we have to determine to what extent both cooperating states can be held responsible for the acts of the community leaders.

According to International Law Commission’s Articles on Responsibility of Slates for Inlernalionally I rongful Acls 200 ( (RSIM X), a contracting state is responsible for extraterritorial violations of human rights, when a state directs and controls another state in the commission of an internationally wrongful act. ${ }^{39}$ Therefore, to hold Hungry responsible, it must be established that IIungary enjoys effective control over migration management at the Subotica reception centre. In the case of I Iungary-Serbia cooperation, smooth rumning of operations regarding the preparation of the list by the SCR and the tacit approval of the list by the Itungarian authorities shows that actions of both states are alien for a common outcome. Therefore, the conduct of the community leaders is of the utmost importance here. Article 8 of the ARSIII A states that the conduct of a person or group of persons shall be considered an act of a state under international law if the person or group of persons is acting on the instruction of, under the direction or control of, that state in carrying out the conduct. ${ }^{\circ}$

In the present case, there exists a special factual relationship between the conduct of the community leaders and the collaborating states. By handing over the list of asylum seekers proposed for admission in the Iungarian transit zones, the Serbian Commissariat passes explicit instruction of delivering the list to the Ilungarian authorities at the transit zones. Similarly, after examination of the proposed list, handing

35 U I General Assembly, Convention Relating to the Stalus of Refugges (adopted on 28 July 19.5, entered into force 22 April 1959), U NTS, vol. 189 , p. 137, Art.33.

$3^{6}$ Council of the European U nion, Charler of the Fundamenlal Rights of the European I nion, supra n. 3 , Arl 4.

37 Council of the European Union, Charler of the Fundamenlal Rights of the European I nion, supra n. 3 I, Art. 3 .

$3^{8}$ Undisclosed interviews with human rights activists in Belgrade, June 2018.

39 International Law Commission, Arlicles on Responsibility of the Slales for Inlernalionally II rongful Acls Vovember

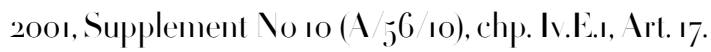

10 Ibid., Ar'. 8. 
over the approved list by the Itungarian authority for delivery to the SCR shows that the conduct of the community leaders has a specific factual relationship with the authorities of both states. Itence, the role of the community leaders correlates to the acts of volunteers, missionaries, or agents working without official capacity commissioned to carry outs specific lasks domestically or overseas. International law wildly attributes responsibility to the state for the conduct of its agents if there exists a specific factual relationship of the agent with the state concerned.'

By providing accommodation and food to the community leaders in the transit zones during their stay at the transit zones to perform the service of communicating the list, Itungary had a factual relationship with the community leaders, which entitle I Iungary to control the conduct of the community leaders. In the case of Cyprus v. Turkey, the Commission on I Iuman Right, the former body of the ECull held that Turkey had effective control on the conduct of private individuals, who violated the rights of Greek and Turkish Cypriots in Northern Cyprus. ${ }^{2}$ The Commission relied on the principle of connivance to attribute responsibility to Turkey for extraterritorial human rights violation at the hands of private parties. State responsibility for the acts of its agents, missionaries, or volunteers has also been recognised in international law in the case of Lehigh Valley, where Germany was held to have effective control on the sabotage activities carried out by private parties in the United States of America. ${ }^{33}$

Furthermore, according to Article I6 of D ARSW A 2001, there could be situations where a state voluntarily or for some other reasons, aids or assists another state by facilitating the commission of a

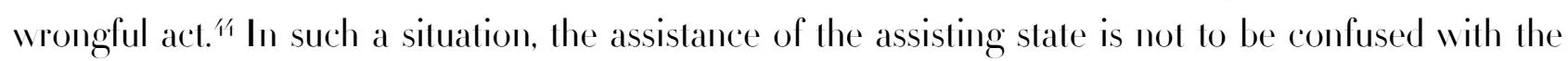
responsibility of the acting state; the assisting state will be responsible for its part of the internationally wrongful act. ${ }^{5}$ Hence, by applying the rule of connivance and considering both states factual control over the conduct of the community leaders, it could be induced that there exists formal cooperation between both states. Thus, it could be argued that Itungary enjoys effective control over the management of the Subotica reception centre and control of irregular migration in Serbia. Therefore, Ilungary could be held responsible for violation of Articles 3 , 1/4 of the ECIIR, Article 4 of the Protocol 4 of the ECIIR, and Article 4, 18,19 and 21 of the CFREU.

\section{(E) IUTIORITY OF TIIE EU L II IX TIIE PRESE YCEOF I IFORM IL BIL ITER ILCOOPER ITIOX}

The idea of unified Europe as a peace project to overcome nationalist forces in the continent and bring peace and prosperity for people of the continent is considered to be the founding narrative of the EU. ${ }^{6{ }^{6}}$

亿 Ibid. S. Fleming, 'Moral Agents and Legal Persons: The Ethies and the Law of State Responsibility' 9(3) Inlernalional

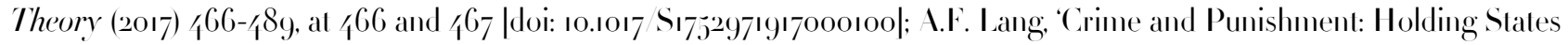
Accountable' 21 (2) Elhics and inlernational affairs (2007) 239-257, al, 239 |doi:10.1111 j.1747-7093.2007.00072|.

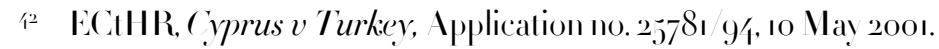

13 Lehigh I ally Railroad Company and Others (Uniled Slales) v Germany, 16 October 1930 \ OLU VIE VIII PP. 8/-10I.

任 MRSIII A, Mrt.ı.

伍 Ibid.

$4^{6}$ I. IIorga and M. Brie, European Identits the Context of Wider Europe' in I). Pantea (ed), The Image of the Others in the European Inlercultural Dialogue (L IP L I I BERT Academic Publishing 2017) 293-311, at 294. 
However, due to the unprecedented arrival of asvlum seekers, Europe has seen a rapid rise in support of nationalist parties, which are critical of the EU addressing the migration crisis inadequately. ${ }^{17}$ Intensified fears about the increasing numbers of refugees and asylum seekers in the European states have increased the vote bank of the populist parties. These parties have been harbouring anti-migration sentiments by depicting existential threat to national security and identity. At the same time, these nationalist parties are also critical of the EU for undermining the Member States' sovereignty and capacity of governing their socielies effectively..$^{8}$

The rhetoric of the nationalist parties in the frontier Member States facing immense irregular arrivals has worked so well that the nationalist parties have managed to form governments in Ilungary, Italy, and Poland. The IIungarian government of the Fidesz nationalist party sees the EU and its common standards established under the Common European Asylum System (CE IS) the main cause of the problem. The CE AS provides a set of Directives and a Regulation, providing common standards to be implemented by the Member States while dealing with asylum applications of third-country nationals. Ilowever, instead of following the CE IS, the practice of some of the Eastern European Member States to implement national measures has become an integration problem for the EU for non-compliance of the EU Law.99

The literature on the securitisation of migration in the Mediterranean shows that the EU, itself, supports informalisation of securitisation of migration by allowing the Member States to disregard the Union's fundamental values of human dignity, the rule of law, solidarity, and equality, with regard to asylum seekers. ${ }^{30}$ The EU-Turkey Migration Statement is the example of informalisation of migration, where the EU hide behind the individual capacity of the Ileads of Member States to conceal the involvement of the Council of the EU to hide legally binding nature of the agreement with Turkey. ${ }^{5}$ This Act of the EU severely undermined the significance of the EU Law by providing a window for informal securitisation measures to bypass the Union's human rights standards and accountability in both supranational European Courts. This informal approach of the EU has also been replicated by Italy, with the support of the EU, to shift the responsibility of migration management to Libva's Government of National Accord

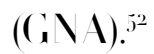

Above discussion shows that the authority and significance of the ECIIR, CFREU, and founding treaties of the EU has been seriously undermined the EU institutions itself. The EU's only problem with Hungary is that Hungary has opted for outright control of migration in clear contrast of the EU Law; while,

17 K. Archick, The European Union: Current Challenges and Future Prospects', Congressional Research Services (2016) I-27, at 5 and 6 (accessed 5 Jovember 2019 ).

48 Ibid. T. A. Borzel, 'From EU Governance of Crisis to Crisis of EU Governance: Regulatory Failure, Redistributive

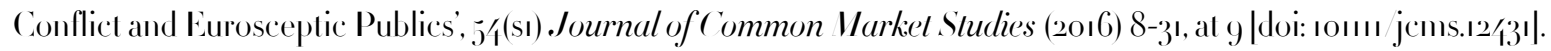

19. Borzel, supra $\mathrm{n}$. 48 , al 22.

$5^{\circ}$ M. Mancin, 'Italy's Vew Migration Control Policy: Stemming the Flow of Migration from Libya without Regard for'

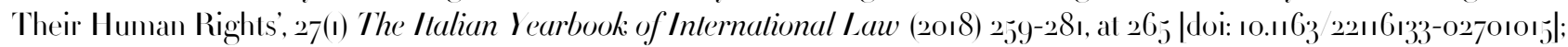
L.B. Adam, 'The EU -Turkey Deal One Year On: A Delicate Balancing Act', .52(4) Inlernalional Speclalor (2017) 作-5, at 作 |doi: 10.108003932729 .2017 .1370569 亿伍.

5. CJEU, judgement of 28 February 2018, NF, NG, N V v. European Council, T-192/16, T-193 ı6, T-257/16, ECLI:EU:T:2017:128.

$5^{2} \quad$ Mancin, supra n. $\jmath^{\mathrm{O}}$ al al 26 . 
the EU prefers it to be done through technical approaches to avoid the impression of undermining the EU Law. In either case, the authority and significance of the EU Law have been severely compromised. In the Hungarian case, even if I lungary reverts to the EU practices, informalisation of migration will continue to have severe implications for the EU Law. Ilowever, at the same time, the implications of informalisation are not limited to refugees and asylum seekers; the fact that the EU Law can be subjugated creates severe concerns about the integration of the EU as more and more Member States will look for informal practices to bypass the EU Law.

\section{(F) CONCLLSION}

Control of irregular migration and asylum through informal migration cooperation with third countries has become the contemporary practice of expanding state authority in the EU. The informalisation of migration and asylum cooperation allows Itungary to pursue its securitisation agenda in Serbia without attracting responsibility, for asylum seekers exclusion from international protection for the reason of cooperating with Serbia. Ilungary's policy of restricling asylum seekers access to the IIungarian transit zones, with the informal assistance of Serbia, is the extreme form of informalisation as the authorities of both states communicate through private persons. This policy of Ilungary undermines the authority of the EU and international law. Iowever, under the EU and international law, both Ilungary and Serbia have effective control on community leader's activity of communicating between the authorities of both states. Therefore, a link establishing cooperation between both states can found by exploring international jurisprudence on the state's responsibility for the acts of a private person. Under the principle of extraterritorial jurisdiction for the acts of a private person, agent, or missionary Hungary attracts the responsible for asylum seekers exclusion from international protection for the reason of controlling, directing, and approving the activities of the SCR. Therefore, the process of informalisation can only be stopped if both the C.JEU and the ECIIIR are willing to play a proactive role by expanding their jurisdiction to informal activities of the Member States beyond the territorial limits of the EU; otherwise, the prospects of the supremacy of the EU and international treaty law look really diminish. 